Patryk Tomaszewski

\title{
Zarys działalności \\ Związku Szlachty Zagrodowej \\ w latach 1938-1939
}

Szlachta zagrodowa, często występująca pod nazwą szlachty zaściankowej, lub też okolicznej (od nazwy zaścianka tzw. okolicy), to nazwa drobnej, ubogiej szlachty, która zazwyczaj musiała utrzymywać się z własnej pracy na roli (najczęściej bez pomocy parobków). Po zniesieniu pańszczyzny własność tej szlachty skurczyła się właściwie do własnej zagrody, stąd też nazwano ją zagrodową. Poza kresami (Wielkie Księstwo Litewskie) największa liczba szlachty zaściankowej występowała w Polsce na Mazowszu i Podlasiu.

Początki osadnictwa szlachty na kresach południowo-wschodnich sięgają czasów Kazimierza Wielkiego. Ówczesne osiedlanie się można nazwać wojskowym, gdyż jego celem byla ochrona poludniowo-wschodnich granic państwa polskiego. Najstarsze nadania dotyczyły rodów rycerskich herbu Sas. Jak pisał senator Władysław Pulnarowicz: „Pierwsi z nich otrzymują od króla Kazimierza Wielkiego w roku 1359 przywilej na Rybotycze w ziemi przemyskiej". W Wiągu kolejnych stuleci coraz więcej rycerstwa przybywalo na te terytoria. Akcja osadnicza szczególnie przybrała na sile po Unii Lubelskiej (1569 r.). Wówczas to drobna szlachta zaczęła kupować ziemię na słabo zaludnionych terenach, spodziewając się, iż będzie to dobra inwestycja. Okazalo się jednak, że nie tylko ludność ta nie pomnożyła majątków, ale uległy one dalszemu rozdrobnieniu. W latach 1772-1848 w znacznym stopniu zrównała się, szczególnie pod względem położenia ekonomicznego, ze społecznością chłopską zamieszkującą tamte ziemie. Szlachta zagrodowa początkowo oczywiście różniła się od chłopów, przede wszystkim ubiorem, zachowaniem instytucji szlacheckich, czy też nakazem brania ślubów w obrębie własnej grupy ${ }^{2}$. Na przestrzeni XIX w. ulegała jednak procesowi zatracenia swojej tożsamości ${ }^{3}$. Pulnarowicz wskazywal, iż przyczyną przejścia szlachty zagrodo-

${ }^{1}$ W. Pulnarowicz, Rycerstwo polskie Podkarpacia, Dawne dzieje i obecne obowigzki szlachty zagrodowej na Podkarpaciu, Przemyśl 1937, s. 19.

${ }^{2}$ Ł. Kapralska, Pluralizm kulturowy i etniczny a odrębność regionalna Kresów poludniowo-wschodnich w latach 1918-1939, Kraków 2000, s. 178.

${ }^{3}$ K. Slusarek, Szlachta zagrodowa w Galicji 1772-1939, [w:] Galicja i jej dziedzictwo. T. H. Spoleczenistwo i gospodarka, pod. red. J. Chłopeczki, H. Madurowicz-Urbańska, Rzeszów 1995, s. 118-119. 
wej z wyznania rzymskokatolickiego na greckokatolickie była znaczna odległość kościołów katolickich od siedzib szlacheckich, co determinowało rozpoczęcie uczęszczania szlachty na msze w cerkwi greckokatolickiej ${ }^{4}$. Do lat trzydziestych XX w. wśród części tej ludności zachowała się pamięć o szlacheckim pochodzeniu. Ten element powodował, iż ludność ta znalazła się w sferze zainteresowania kół rządowych Drugiej Rzeczypospolitej. Szlachta zagrodowa miała się stać, według władz, narzędziem rewindykacji polskości na kresach. Oczywiście należy podkreślić, iż przez „szlachectwo" rozumiano wyłącznie świadomość historyczną swego pochodzenia, gdyż należy pamiętać, iż utrata przywilejów szlacheckich nastąpiła w XIX wiekus.

Szlachta zagrodowa zamieszkiwała małe zaścianki głównie w województwie lwowskim, tarnopolskim i stanisławowskim ${ }^{6}$. Osiemdziesiąt procent osób spośód szlachty było wyznania grekokatolickiego, $90 \% \mathrm{z}$ nich mówiło $\mathrm{w}$ języku ukraińskim, zaś $20 \%$ zaliczało się do narodowości polskiej. Dane te wskazują, iż $10 \%$ spośród mówiących po ukraińsku określało się jako ludność polska, co wskazywać mogło na szansę pozyskania w procesie repolonizacyjnym również kolejnych osób nie mówiących po polsku. Z tego też względu podkreślano historyczne związki szlachty z Polską. Jak pisał przytaczany już Władysław Pulnarowicz: „Szlachta zagrodowa Podkarpacia jest potężną siłą od wieków włodarzącą na południowej rubieży Rzeczypospolitej. Wyrosła ona $\mathrm{z}$ tej ziemi i od wieków pracą, krwią i znojem buduje na tej ziemi życie polskie, od wieków z woli Bożej tu osadzona pilnuje południowych granic naszej Ojczyzny"?.

\section{TWORZENIE RUCHU REWINDYKACYJNEGO}

Zagadnienie szlachty zagrodowej przybliżył opinii publicznej Pulnarowicz, który w roku 1929 wydał książę „U źródeł Stryja, Sanu i Dniestru”, gdzie zwracał uwagę na szlachtę zagrodową, wskazując na jej polskie korzenie. Datą początkową akcji mającej na celu „przywrócenie do polskości” drobnej szlachty w Małopolsce Wschodniej był rok 1934. Wówczas to koordynacją akcji repolonizacyjnej zajął się Sekretariat Porozumiewawczy Polskich Organizacji Społecznych ${ }^{8}$, z ramienia

4 W. Pulnarowicz, op.cit., s. 29. Podobnie twierdził Prokop Sas (Marceli Prószyński), Szlachta zagrodowa, Lwów (b.r.w), s. 16. Słabość parafii rzymskokatolickich wplywała również na rejestrację zgonów, urodzeń, ślubów w bliższych parafiach greckokatolickich.

${ }^{5}$ W latach 1772-1848 szlachta zagrodowa utracila prawa do posiadania dominium i poddanych, prawo do odrębnego sądownictwa, prawo do udziału w życiu politycznym. Zob. K. Ślusarek, op.cit., s. 117.

${ }^{6}$ Ponadto rody szlachty zagrodowej zamieszkiwały na terenie województwa wołyńskiego i podlaskiego oraz białostockiego. W latach trzydziestych szacowano, że liczba szlachty zagrodowej sięga w regionie podkarpackim 300 tys., regionie podolskim 60-80 tys., regionie wolyńskim 100-150 tys., regionie poleskim 100 tys., regionie północnym (niektóre rejony województwa białostockiego) 200-250 tys. osób. Zob. M. Kasprzak, Towarzystwo Rozwoju Ziem Wschodnich 1933-1939, Łódź 2005, s. 101.

${ }^{7}$ W. Pulnarowicz, op.cit., s. 59.

${ }^{8}$ W skład sekretariatu wchodzily różne związki i stowarzyszenia, takie jak Towarzystwo Szkót Ludowych, Towarzystwo Rozwoju Ziem Wschodnich, Komitet Pomocy Dzieciom, Związek Strze- 
którego akcję prowadziło głównie Towarzystwo Rozwoju Ziem Wschodnich, przy współpracy ze Związkiem Strzeleckim i Towarzystwem Szkół Ludowych oraz Małopolskim Towarzystwem Rolniczym. Początkowo akcję rozpoczęto w powiecie turczyńskim w województwie lwowskim ${ }^{9}$ Na szlachtę zagrodową zwrócono także uwagę w kręgu oficerów komisji poborowych w Przemyślu, którzy zauważyli, $\mathrm{iż} \mathrm{część} \mathrm{poborowych} \mathrm{wyznania} \mathrm{greckokatolickiego} \mathrm{posiada} \mathrm{zruszczone} \mathrm{nazwiska.}$ Zjawisko to opisał w 1939 r. Jan Korab-Wojciechowski, sekretarz Zarządu Glów. nego Związku Szlachty Zagrodowej: „Zgłasza się do wojska żołnierz jako Dobriańskij, choć ojciec jego w metryce najwyraźniej ma Dobrzyński. Drugi podaje nazwisko Krijanowskij, mimo że każdy jego przodek nazywał się Krzyżanowski, 2 Dzika zrobili Dyka, nazwisko Wilczyński zamieniono na Wołk, sam podpisuje się Sulima, a w metryce ma Sołyma, nie mówi nawet po rusku i podpisuje się Ryklik Jan, a w metryce ma Ryłow Iwan. Przykładów można podać setki i tysiące. W przemyskim pułku strzelców podhalańskich służyło trzech braci stryjecznych, $z$ których jeden w metryce miał wpisane Demkowicz Białas, drugi Białas, a trzeci już Biłas. Najlepiej to ilustruje, jak postępowała taka zmiana"10.

W kręgach wojskowych najbardziej zainteresowany kwestią repolonizacji szlachty zagrodowej był gen. Janusz Gluchowski. Z jego inicjatywy zwołano międzyministerialną naradę, która odbyla się dnia 15 XI 1937 roku w Ministerstwie Spraw Wojskowych (MSWoj.). Wtedy to współpracownik gen. Głuchowskiego, pplk. Stanisław Sadowski zaprezentowal przyjęty przez MSWoj. program prac w kwestii szlachty zagrodowej. Wskazał, iź akcja ma na celu rewindykację i asymilację szlachty Podkarpacia ${ }^{11}$. Efektem narady było powołanie dnia 25 II $1938 \mathrm{r}$. Komitetu do Spraw Szlachty Zagrodowej na Wschodzie Polski, formalnie działającego przy Towarzystwie Rozwoju Ziem Wschodnich ${ }^{12}$. Głównym terenem działania komitetu była Małopolska Wschodnia, w dalszej zaś kolejności Wolyń. Przewodniczącym komitetu został Gołuchowski, pierwszym wiceprzewodniczącym Tadeusz Garbusiński, drugim ppłk. Stanisław Sadowski. Komitet działał w czterech sekcjach: naukowej, propagandowej, gospodarczej i finansowej. W komitecie istotne miejsce zajmowała sekcja naukowa, która zajmowała się badaniami nad osadnictwem na kresach, historią szlachty zagrodowej, miejscami jej zamieszkiwania ${ }^{13}$.

W ramach akcji rewindykacyjnej na kresach $z$ ramienia Sekretariatu Porozumiewawczego Polskich Organizacji Społecznych działało więc Towarzystwo Rozwoju Ziem Wschodnich, a w szczególności autonomiczny Komitet do Spraw

lecki. Centrala organizacja, jaką był sekretariat, miała za zadanie przede wszystkim zespolić polskie organizacje społeczne na kuesach, celem skuteczniejszego działania. Zob. W. Paruch, Od konsolidacji państwowej do konsolidacji narodowej. Mniejszości narodowe w mysli politycznej obozu pilsudczykowskiego (1926-1939), Lublin 1997, s. 347.

${ }^{9}$ M. Kasprzak, op.cit., s. 99.

${ }^{10}$ Cyt. za: J. P. Jarosz, Akcja repolonizacji na terenach poludniowo-wschodnich Rzeczypospolitej w latach 1935-1939, www.kki.pl/pionf/przemysl/dzieje/rus/repolonizacja.html (przeglądana 18 II 2007).

${ }^{11}$ M. Kasprzak, op.cit., s. 103.

12 J. P. Jarosz, op.cit.

${ }^{13}$ Szerzej zob. M. Kasprzak, op.cit., s. 110-114. 
Szlachty Zagrodowej na Wschodzie Polski, ponadto Towarzystwo Szkół Ludowych, Związek Strzelecki, Małopolskie Towarzystwo Rolnicze, a także najprężniejsza z organizacji - Związek Szlachty Zagrodowej.

\section{POWSTANIE ZWIĄZKU SZLACHTY ZAGRODOWEJ}

Przelomowym wydarzeniem w integracji środowisk szlachty był Zjazd Szlachty Zagrodowej, który odbył się dnia 17 października 1937 roku w Teatrze Wielkim we Lwowie. Wzięło w nim udział ok. 4 tys. delegatów kół szlacheckich ${ }^{14}$. Celem zjazdu miało być stworzenie Związku Szlachty lączącego poszczególne koła w jedną organizację. Jak pisał Prokop Sas ${ }^{15}$ : „Pragniemy, więc stworzyć we Lwowie Związek Szlachty, przede wszystkim na to byśmy wzajemnie o sobie wiedzieli, a nadto, byśmy sobie pomagali. Szczególnie chodzi o pomoc w wykształceniu dzieci, które posyłamy do szkół nieraz z wielkim trudem"16. Na zjeździe podjęto decyzję o utworzeniu Związku Szlachty Zagrodowej Podkarpacia, w tym celu powołano komisję mającą za zadanie opracowanie statutu i programu działalności. Organizacja o nazwie Związek Szlachty Zagrodowej (ZSzZ) ${ }^{17}$ oficjalnie powstała 13 lutego 1938 roku na Zjeździe Ogólnym Szlachty Zagrodowej w Przemyślu. Na czele związku stanąl ksiądz dziekan płk. Antoni Miodyński18, kapelan 5 pułku Strzelców Podhalańskich. We wspomnianym zjeździe wzięly udział osoby, które patronowały związkowi: gen. bryg. Janusz Głuchowski - wiceminister spraw wojskowych, gen. bryg. Wacław Scaevola Wieczorkiewicz - dowódca Okręgu Korpu-

${ }^{14}$ Koła szlacheckie zaczęły powstawać $z$ inicjatyw Związku Strzeleckiego. Pierwsze w powiecie turczyńskim. W 1935 r., liczyły jedynie 500 członków. W 1939 roku Związek Szlachty Zagrodowej (ZSzZ) liczył w już 49 tys. osób (wspólnie dla Małopolski Wschodniej i Wołynia). Zob. J. P. Jarosz, op.cit.; M. Kasprzak, op.cit., s. 100.

${ }^{15}$ Prokop Sas - pseudonim Marcelego Prószyńskiego, znawcy zagađnień demograficznych na Kresach.

${ }^{16}$ P. Sas, Szlachta zagrodowa, Lwów (b.d.w.), s. 21.

${ }^{17} \mathrm{Na}$ terenach pólnocno-wschodnich, w powiatach grodzieńskim, wołkowyskim i szczuczyńskim powstał Związek Zaściankowy. Zob. M. Kasprzak, op.cit., s. 100.

${ }^{18}$ Antoni Miodyński: ksiądz dziekan i pukkownik WP. Urodził się 26 marca 1889 roku w Zywcu jako syn Wincentego i Karoliny Molińskiej. Zmarł 4 lutego 1949 roku w Zywcu i pochowany został na miejscowym cmentarzu. Czlonek niepodległościowej organizacji „Wolnośc”. Służył w wojsku Austro-Węgierskim od kwietnia 1915 do sierpnia 1916 roku kapelan 56. putku piechoty na froncie rosyjskim, gdzie dostał się do niewoli, w której przebywal do maja 1917 roku, następnie w obozie dla inwalidów Habel w Danii do grudnia 1917 roku, potem w szpitalu w Wiedniu do lutego 1918 r., później w 20. galicyjskim pułku piechoty na froncie wloskim do 12 listopada 1918 roku. W armii polskiej: od 13 listopada 1918 do marca 1920 roku w 1. pulku strzelców podhalańskich (współtwórca Uniwersytetu Żołnierskiego w Nowym Sączu), następnie do grudnia 1921 roku w 1. Dywizji Piechoty Górskiej, od stycznia 1922 do sierpnia 1939 roku byl kierownikiern Rejonu Duszpasterstwa Katolickiego i proboszczem w Bielsku, po kampanii wrześniowej 1939 roku w Polskich Siłach Zbrojnych na Zachodzie jako szef słuźby duszpasterskiej 3. Brygady Kadrowej Strzelców, po zakończeniu II wojny światowej powrócil do Polski. Odznaczony był m.in.: dwukrotnie Krzyzem Walecznych, Złotym Krzyżem Zasługi, Medalem Pamiątkowym za Wojnę 1918-1921, Medalem Dziesięciolecia Odzyskanej Niepodległości. 
su X w Przemyślu, a także wojewoda stanisławowski - Stefan Pasławski oraz wicewojewoda lwowski Gustaw Chmielewski.

Struktura związku przedstawiała się następująco. Najmniejszą jednostką związku było koło. Przedstawiciele kół z danego obszaru tworzyli zarządy powiatowe, przedstawiciele tych zarządów zasiadali w zarządach okręgowych. Pracami ZSzZ kierował Zarząd Główny, na czele którego stał prezes.

W roku 1935 przy Towarzystwie Rozwoju Ziem Wschodnich założono czasopismo „Pobudka”, wydawane początkowo w Tuce nad Stryjem, zaś rok później redakcja przeniosła się do Przemyśla. W roku 1937 pismo stało się dwutygodnikiem, od 1938 wydawcą „Pobudki” został Zarząd Główny Związku Szlachty Zagrodowej ${ }^{19}$. „Pobudkę" w roku 1935 prenumerowało 300 osób, zaś w 1938 r. już 11 tys. Ponadto zaczęto wydawać dodatek dla dzieci "Mała Pobudka”, a wraz z rozwojem ZSzZ na województwo wołyńskie w Kucku wydawano „Pobudkę wołyńską". W roku 1939 „Pobudka” osiągnęła nakład 15 tys. egzemplarzy ${ }^{20}$. Wychodziły również broszury dotyczące szlachty zagrodowej" ${ }^{21}$.

Ważnym wydarzeniem w historii związku było objęcie honorowego patronatu nad jego pracami przez marszałka Edwarda Smigłego-Rydza, jak donosiła „Pobudka”: "Dzień 24 czerwca 1938 roku stał się pamiętny dla Związku Szlachty Zagrodowej. Pan Marszałek Edward Smigły-Rydz przyjał osobiście hołd szlachty zagrodowej i wyraził zgodę na roztoczenie Swego Wysokiego Protektoratu nad pracami Związku Szlachty Zagrodowej, które zmierzają ku wzmocnieniu dawnych rycerskich cnót i odnowienia dawnych zołnierskich obowiązków służby Najjaśniejszej Rzeczypospolitej wśród wielkich mas szlachty zagrodowej naszej ziemi"22.

\section{DZIALALNOŚĆ ZWIAZZKU}

Związek Szlachty Zagrodowej cieszył się dość dużym zainteresowaniem inteligencji. Losami szlachty interesowaty się takie osoby jak chociażby pisarki Maria Rodziewiczówna, Zofia Kossak-Szczucka, pisarze Kornel Makuszyński, Gustaw Morcinek, Ferdynand Ossendowski. Ten ostatni napisał nawet dwie książki poświęcone życiu szlachty zagrodowej „Orły Podkarpacia” oraz „Pod sztandarami Sobieskiego".

Związek organizował liczne koła, których liczba w roku 1939 w Małopolsce Wschodniej wynosiła 450 z 41 tys. członków. Związek rozszerzyl swoją działalność na teren Wołynia, gdzie w roku 1939 istniało 181 kól, do których należało 8 tys. osób ${ }^{23}$.

${ }^{19}$ J. P. Jarosz, op.cit.

${ }^{20}$ Ibidem.

${ }^{21}$ Zob. Prokopa Sasa, Szlachta zagrodowa, Lwów (b.rw.), Roman Horoszkiewicz, Szlachta zaściankowa na ziemiach wschodnich, Warszawa 1936, Wladyslaw Pulnarowicz Rycerstwo Polskie Podkarpacia, Dawne dzieje i obecne obowiazki szlachty zagrodowej na Podkarpaciu, Przemysil 1937, Bolesław Demkiewicz-Dobrzyński, Szlachta zagrodowa Ziemi Czerwieńskiej, jej pochodzenie i przeszlość, Stanisławów 1938 (również po ukraińsku), Stanisław Jastrzębski, Kim jesteśmy? O szlachcie zagrodowej w Malopolscy Wschodniej, Przemyśl 1939 (również po ukraińsku).

${ }^{22}$ Pobudka, nr 14, 15 VII, 1938, s. 1.

${ }^{23}$ M. Kasprzak, op.cit., s. 109. 
Dla członków związku tworzone były czytelnie, organizowano kursy: kierowników świetlic, kroju i szycia, sekretarzy kół. Związek starał się, aby ludność z nim powiązana miała dobrą opiekę duszpasterską. Budowano i wyposażano kościoły. W czasie Wielkiego Postu prowadzono rekolekcje. Przykładem może być miejscowość Krynica Szlachecka, gdzie zaproszony ksiądz greckokatolicki wygłaszał kazania w języku polskim ${ }^{24}$. Na potrzeby związku wybudowano w kilkunastu miejscowościach domy ludowe ze świetlicami, salami teatralnymi, powstawały także sklepiki spółdzielcze ${ }^{25}$. Organizowano ogniska, na których deklamowano patriotyczne wiersze. Działacze związku w poszczególnych kołach obchodzili święta państwowe, jak chociażby 3 maja. Dużą uwagę zwracano na podnoszenie wykształcenia młodych. Z tego względu fundowano stypendia szlacheckie dla młodzieży, która uczęszczała do gimnazjów. W Bohorodczanach w województwie stanisławowskim otworzono szkołę gospodarstwa domowego. Prezes związku podkreślał, iż ideałem do którego dąży jest, aby: „każda dziewczyna $z$ naszego Związku po ukończeniu 16 lat życia przeszła 5 miesięczny kurs gospodarstwa domowego"26. Chcąc podnieść higienę wśród działaczy związku, przygotowywano również kursy „przewodniczek sanitarnych". Utworzono ponadto 120 chórów i 40 orkiestr ${ }^{27}$. Dla dzieci $z$ rodzin szlachty zagrodowej organizowano kolonie i półkolonie m.in. w Rabce. W wojsku utworzono kompanie szlacheckie. Pierwsza $z$ nich powstała już $w$ roku 1936 w 5 pułku Strzelców Podhalańskich w Przemyślu. W październiku kompania szlachecka zameldowała się u prezydenta Ignacego Mościckiego. Prezydent stał się również ojcem chrzestnym kilkorga dzieci z rodzin szlachty zagrodowej28. Dużym przedsięwzięciem przygotowanym przez Związek Szlachty Zagrodowej była wycieczka przedstawicieli związku po Polsce. W czerwcu 1938 r. odwiedzono wówczas następujące miasta: Przemyśl, Kraków, Wieliczkę, Katowice, Chorzów, Poznań, Gdynię, Warszawę

Warto podkreślić, iż dużą atencją wśród działaczy związku cieszył się przewodniczący ks. płk. Miodyński. Występowały nawet pewne elementy kultu jego osoby. W czasie wielu uroczystości szlachty zagrodowej wznoszono np. okrzyki "niech żyje Wódz Rydz-Śmigły”, co w drugiej połowie lat trzydziestych było dość powszechne, ale również skandowano na cześć Miodyńskiego. W jednym $z$ numerów „Małej Pobudki”, ukazał się z okazji imienin prezesa związku czołobitny wierszyk, w którym czytamy:

„[...] Dziś hołd Tobie składamy serdecznie

Księże Prezesie, boś Ty Wódz jest nasz.

${ }^{24} Z$ życia naszych ziem i kót Z.S.Z, Pobudka, nr 10, 15 V 1939, s. 14; J. P. Jarosz, op,cit.

${ }^{25} \mathrm{~J}$. P. Jarosz, op.cit.

${ }^{26}$ A. Miodyński, Z.S.Z niesie kulturę na ziemie poludniowo wschodnie. Przemówienie Prezesa Zwiazku Szlachty Zagrodowej Ks. Plk. Antoniego Miodyńskiego wygloszonego przez radio w dniu 8 VI 1939 r., Pobudka, nr 12, 15 VI 1939, s.7.

${ }^{27}$ Ibidem.

${ }^{28}$ Pobudka, nr 14, 15 VII, 1938, s. 11.

${ }^{29}$ Ibidem, s. 2. 
I ślubujemy Polskę kochać wiecznie

I u jej granic wierną trzymać straż!"30.

Interesujący jest również fakt, iż ZSzZ zainteresował się przywódca Ruchu Narodowo-Radykalnego "Falanga” - Bolesław Piasecki. W latach trzydziestych przedsięwziął on plan „penetracji” różnych organizacji przez działaczy „Falangi”. Jak piszą biografowie Piaseckiego: „Obiektem jego zainteresowania (Piaseckiego - P. T.) stał się Związek Szlachty Zagrodowej - wspierany przez II Oddział Sztabu Generalnego, organizacja skupiająca zubożałą, zukrainizowaną szlachtę polską. W lutym 1939 r., na polecenie Piaseckiego, jednym $z$ redaktorów »Pobudki organu prasowego ZSzZ - został Włodzimierz Sznarbachowski. Po nim podjęli pracę w ZSzZ dwaj inni członkowie RNRu: Jan Olechowski i Mieczysław Chądzyński. Cała akcja, prowadzona w ścisłym porozumieniu $z$ wiceministrem Gluchowskim, była zgodna nie tylko $z$ falangistowskim planem polonizacyjnym, ale zapewniala także określone korzyści natury finansowo-organizacyjnej" ${ }^{31}$. Niestety jest to informacja oparta wylącznie na jednym źródle, a mianowicie liście wspornnianego Sznarbachowskiego, wskazuje jednak, na jeszcze jeden wątek przyczyniający się do powstania związku, a mianowicie zainteresowanie wywiadu środowiskiem szlachty zagrodowej.

\section{ZWLAZEEK SZLACHTY ZAGRODOWEJ JAKO NARZĘDZIE REPOLONIZACJI KRESOW POEUDNIOWO-WSCHODNICH}

Wszystkie działania władz w stosunku do szlachty zagrodowej miały za zadanie przyciągnięcie tej grupy obywateli do polskości, $\mathbf{z}$ tego powodu podkreślano rycerską przeszłość i rolę, jaką w obronie południowo-wschodnich rubieży odgrywała osiadła tam szlachta. Przypominano również o udziale poszczególnych rodów szlacheckich w walce o niepodległość. Przywoływany już Pulnarowicz podawal kilka stron imion i nazwisk szlachty pochodzącej z terenów południowo-wschodnich, a walczącej np. w powstaniu styczniowym, obronie Lwowa, czy też wojnie polsko-bolszewickiej. Wśród nazwisk znajdujemy takie osoby jak: Tadeusz Monasterski, który był adiutantem Komendanta Głównego (Józefa Piłsudskiego) Związku Strzeleckiego, czy też Stanisław Tymkowicz-Krynicki oficer Komendy Głównej tegoż Związku ${ }^{32}$.

Akcja mająca na celu repolonizację tej grupy przyniosła pewne rezultaty, biorąc pod uwagę zorganizowanie w ciągu kilku lat dość licznej grupy działaczy związku. Faktem jest, iż związek przyczynił się do aktywizacji zubożałej szlachty, poza tym faktycznie integrował to środowisko, chociaźby przez wspólne spędzanie czasu. Ważnym elementem była dość duża aktywność władz w organizacji kół związku. Pamiętać przy tym należy o złym położeniu ekonomicznym tej lud̆ności,

\footnotetext{
${ }^{30}$ Mała Pobudka, nr 12, 15 VI 1939, s. 2.

${ }^{31}$ A. Dudek, G. Pytel, Boleslaw Piasecki. Próba biografii politycznej, Londyn 1990, s. 97.

${ }^{32}$ W. Pulnarowicz, op.cit., s. 55.
} 
działalność związku, przy silnej kurateli państwa, mogła przyczynić się do poprawy sytuacji materialnej szlachty zagrodowej. W tym celu stworzono właśnie Fundusz Pożyczkowo-Zapomogowy, udzielający kredytów na cele gospodarcze, jak kupno narzędzi rolniczych, czy też nawozów sztucznych ${ }^{33}$. Zorganizowano także wycieczkę do Danii mającą na celu zapoznanie się z tamtejszymi sposobami "go. spodarowania”. Działania związku podnoszące z jednej strony wykształcenie i świadomość szlachty zagrodowej, często "przywracanie" jej dla języka polskiego, mocne akcentowanie powiązania historycznego tej ludności z polskością, przy zwiększeniu jej aktywności miało na celu zahamowanie rutenizacji. Proces ten dość obrazowo został nakreślony przez Jerzego Stempowskiego, który pisał: „W 1936 r. oglądałem z Piotrem Bokowskim pod Trembowlą stare, katolickie wsie polskie, których mieszkańcy od pewnego czasu zaczęli w domu mówić po ukraińsku. Zjawisko to nie jest nowe. Proces taki odbył się już przedtem na Litwie, gdzie potomkowie Horeszków i Sopliców porzucili częściowo język polski dla litewskiego. [...] Wydaje mi się, że zjawisko to nie ma żadnych reguł ogólnych i w każdym wypadku wynika $z$ określonych przyczyn lokalnych. W ciaggu ostatnich 10 lat przed wojną spędziłem corocznie parę miesięcy na Wolyniu i w Galicji Wschodniej i miałem sposobność zapoznania się $z$ warunkami, w których język polski zaczął ustępować ukraińskiemu, mimo presji szkolnej i administracyjnej. Główną przyczyną tego zjawiska, wydaje mi się być zubożenie wsi polskiej w inteligencję i obniżenie kwalifikatywne tej ostatniej. Kto ukończył szkoły zostawał urzędnikiem lub jednym $\mathrm{z}$ niezliczonych oficerów WP. Inteligencja ukraińska pozostawała na wsi i życie wewnętrzne wsi ukraińskiej stało się bardziej bogate i pociągające od $\dot{z}$ ycia wsi polskiej"34.

Najważniejszym działaniem Związku Szlachty Zagrodowej byly próby silnego związania szlachty zagrodowej $z$ Polską. Temu służyly wydawnictwa propagandowe, również w języku ukraińskim, które miały za zadanie budzić świadomość historyczną. Szczególną uwagę działacze związku zwracali na wychowywanie przyszlych pokoleń. Jak pisał prezes Miodyński: „W pracy naszej nie ludzimy się, abyśmy mogli szybko osiągnąć wyniki, bo aby wychować jedno pokolenie, trzeba co najmniej 20 lat"3s. Związek Szlachty Zagrodowej staral się również wplywać na ocenę Cerkwi greckokatolickiej przez szlachtę. „Pobudka” wyrażała dość interesujące stanowisko $w$ czasie, gdy istniały spore kontrowersje dotyczące układu zawartego pomiędzy Stolicą Apostolską a Polską, dotyczącego dóbr pounickich (na Chełmszczyźnie i Podlasiu). Miały one zostać przejęte przez Kościół katolicki. Przeciwko układowi opowiadali się zwolennicy ukraińskiej irredenty. W jednym $z$ numerów pisma działacze związku pisali: „Walcząc o oczyszczenie atmosfery wśród naszej szlachty zagrodowej, polskiej $z$ narodowości, a religijnie przeważnie związanej $z$ obrządkiem grecko-katolickim - mamy prawo i obowiązek domagać się tego:

\footnotetext{
${ }^{33}$ I. P. Jaros2, op.cit.

${ }^{34}$ J. Stempowski, W Dolinie Dniestru, Lisfy o Ukrainie, Warszawa 1991, s. 197.

${ }^{35}$ A. Miadyński, op.cit., s. 7.
} 
1) żebyśmy nie stanowili w Cerkwi wiernych drugiej klasy i żeby Cerkiew reprezentantka naszych wierzeń i uczuć religijnych dawała nam pełne ich zaspokojenie i równocześnie

2) żeby wychowywała nas w pełnym poszanowaniu naszej godności narodowej polskiej i gotowości do służby celom ogólnym, dobru wspólnemu - przez wpajanie szacunku i oddania wlasnemu państwu, Rzeczypospolitej Polskiej.

Dlatego jako Polacy greko-katolicy nie możemy dłużej milczeć, gdy widzimy jak Cerkiew gr. kat. staje się aż nazbyt często narzędziem polityki wrogiej naszemu narodowi $[. . .]^{336}$. Zainteresowanie związkiem ze strony szlachty zagrodowej doprowadziło do prób zorganizowania przez stronę ukraińską ruchu bojarów. Natomiast nacjonaliści ukraińscy stosowali także metody terrorystyczne, poprzez napady na poszczególnych działaczy związku. W Chomczynie (woj. stanisławowskie) został nawet zamordowany prezes Koła Związku Szlachty Zagrodowej - Andrzej Rozwadowski ${ }^{37}$.

Efektem działań Związku Szlachty Zagrodowej było zapobieżenie dalszej rutenizacji części szlachty i zwiększenie jej aktywności społecznej. Nie można dziś jednoznacznie odpowiedzieć, jak potoczylby się rozwój związku, gdyż zostal on zahamowany przez wybuch wojny. Wydaje się jednak, że mimo wsparcia władz państwowych, część inicjatyw działacze związku podejmowali oddolnie, co przy szczególnym zwróceniu uwagi na wychowanie młodego pokolenia mogło skutkować zwiększeniem polskiej świadomości narodowej wśród tej ludności ${ }^{38}$. Jak pisze Krzysztof Ślusarek, przywiązanie do polskości wśród części szlachty zagrodowej przetrwało do drugiej połowy XX w. „Przykładem może być przypadek wsi Baczyna, której mieszkańcy - potomkowie szlachty zagrodowej - po roku 1957, w ramach akcji repatriacji, przenieśli się na polskie ziemie zachodnie"39.

${ }^{36}$ S. K., Nowa „kryuda" ukrainska?!, Pobudka, nr 15, 1 VIII 1938, s. 8.

${ }^{37}$ J. P. Jarosz, op.cit.

${ }^{38}$ Działalność związku była jednoznacznie niechętnie oceniana przez Jerzego Giedroycia. Zob. Jerzy Giedroyć, Autobiografia na cztery ręce, Warszawa 1996, s. 41.

${ }^{39}$ K. Slusarek, op.cit., s. 120. 